\title{
Canadian pulp fibre morphology: Superiority and considerations for end use potential
}

\author{
by Paul Watson ${ }^{1}$ and Michael Bradley²
}

\begin{abstract}
Four physical attributes of fibres confer the end use potential of a pulp, namely fibre length, fibre coarseness, fibre strength and uniformity. Long, slender, fine fibred pulps, which are low in thick-walled summerwood content, provide superior reinforcement strength. The natural species endowment that Canada enjoys can, when accompanied by superior operational performance and technical vision, result in significant advantages for strategically focused companies and their customers. Factor and multivariate analysis of more than 60 industrial pulp samples confirm that on the basis of fundamental morphological differences, Canadian pulps exhibit clear superiority. Canadian northern bleached softwood kraft pulp is the undoubted industry leader, yet unrealized potential still exists, and additional research effort is required, to maintain this market position.
\end{abstract}

Key words: kraft pulp, softwood, fibre morphology, intrinsic properties, length, coarseness, fibre strength, tensile strength, biogeoclimatic zone, factor analysis, reinforcement, premium reinforcement pulp, PRP, refining

\section{RÉSUMÉ}

Quatre propriétés physiques des fibres de conifères déterminent le potentiel d'utilisation finale d'une pâte, soit la longueur de la fibre, sa grossièreté, sa résistance et son uniformité. Les pâtes formées de fibres longues et minces qui contiennent peu de bois dété aux parois épaisses permettent d’accroître la résistance à un niveau supérieur. Le grand choix d’espèces naturelles dont bénéficie le Canada permet, lorsqu’une performance opérationnelle attentive et qu’une vision technique supérieure sont en place, de générer des bénéfices significatifs pour les entreprises stratégiquement orientées et pour leurs clients. Une analyse factorielle et multivariée de plus de 60 échantillons de pâte industrielle confirme quen fonction des différences morphologiques fondamentales, les pâtes produites au Canada détiennent une supériorité évidente. La pâte kraft blanchie produite à partir de résineux nordiques du Canada savère être incontestablement le leader mondial, quoique son plein potentiel nest pas encore atteint et que des efforts additionnels de recherche sont requis afin de maintenir cette position sur les marchés.

Mots clés : pâte kraft, résineux, morphologie des fibres, propriétés intrinsèques, longueur, grossièreté, résistance, résistance à la traction, zone biogéoclimatique, analyse factorielle, renforcement, pâte de renforcement, PRP, perfectionnement

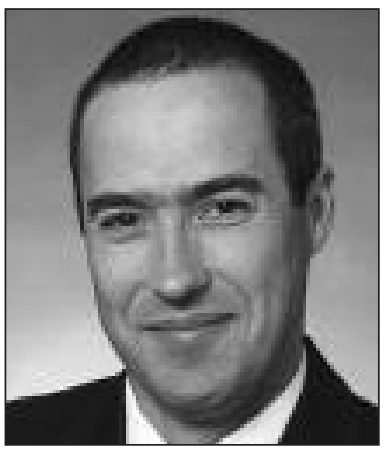

Paul Watson

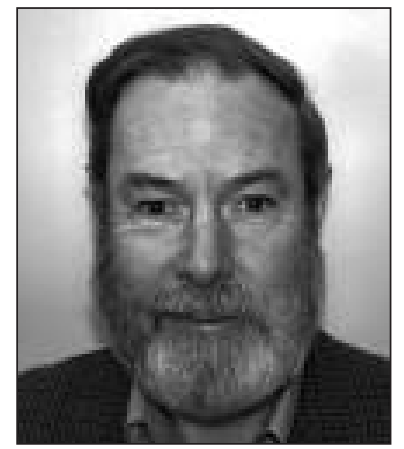

Michael Bradley

\section{Introduction}

In the 1990s, the consulting group Jaakko Pöyry released the matrix shown in Fig. 1, which identified the key competitive requirements for forest products companies, their evolution and predictions to ensure ongoing competitiveness. This

matrix provided much of the guidance for Paprican's fibre supply and quality program at the time, and is as relevant today as it was 10 years ago. A review of the successful companies worldwide confirms these predictions.

What of Canada? Our forest products industry is regularly criticized by analysts decrying destruction of capital in our plants. Consequently, cost reduction has completely supplanted technology investment as the driver for many companies. Furthermore, the resultant lack of investment has led to the demise of many companies, while our competitors continue to invest heavily in R\&D and strategically implement technology focused on cost and quality improvement, the results of which speak for themselves.

Canfor Pulp Limited Partnership (CPLP) is one of the Canadian pulp and paper industry's lowest-cost producers, is the largest single source of green power in North America, and its northern bleached softwood kraft pulp (NBSK) has the global reputation as one of the world's premier softwood fibre-PRP or Premium Reinforcing Pulp. CPLP's fibre endowment consists of spruce, pine and true fir (SPF), which

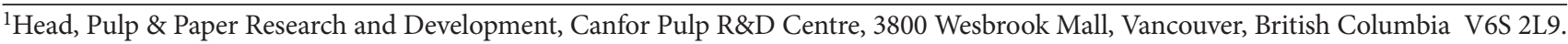
E-mail: paul.watson@canforpulp.com

${ }^{2}$ Director, Technology and Sustainability, Canfor Pulp L.P., 1700 West 75th Ave., Vancouver, British Columbia V6P 6G2. E-mail : michael.bradley@canforpulp.com
} 


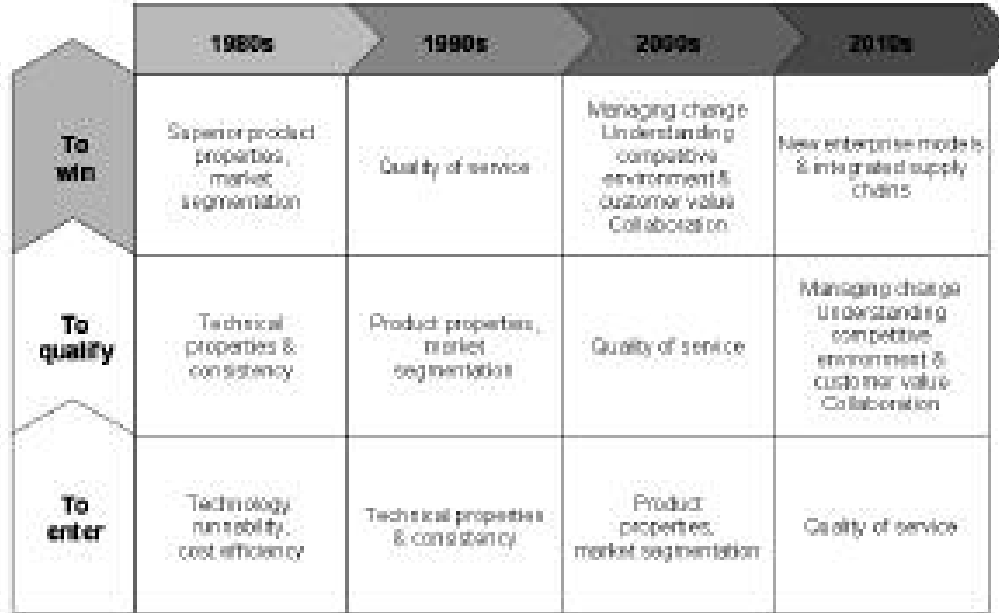

Fig. 1. Matrix conferring the competitive requirements of pulps (Jaakko Pöyry). grow on the central plateau of British Columbia within a relatively consistent biogeoclimatic zone. These slow-growing species (historically, Prince George experienced an average of 90 frost-free days per year) provide the unique attributes of the fibres that go into our pulps. Many other softwood pulp-producing regions of Canada enjoy generally similar conditions and, if marketed wisely, their pulps too confer a "Canadian Advantage."

Fibre Attributes of Canadian Tree Species - An Overview

Pulp fibres are the trees' tracheids. They confer strength to the tree, dictate solid wood properties (including bending strength, stiffness and basic density), and can be disassembled during the pulping process for reassembly into a remarkably diverse range of products ranging from paper grades through filtration media to advanced composites. The production process is close to being carbon-neutral, as pulp fibres both store carbon and are $100 \%$ recyclable (Joint FPAC/WWF Press release, October 31st 2007) $)^{3}$.

Pulp fibres are composed of a primary cell wall, a complex 3 -layered secondary wall, and an open lumen. The characteristics of the secondary cell wall S2 layer confer most of the properties to the fibre, as it represents the bulk of the fibre. It is composed of cellulose fibrils that are embedded in a lignin and hemicellulose matrix. In normal wood, the cellulose fibrils in the S2 layer are wrapped around the fibre at an angle less than $30^{\circ}$ to the longitudinal axis of the fibre. In the simplest terms, the relative mass of the fibre cell wall is reported as coarseness, or weight in milligrams of fibre per unit length, which can be measured using an optical analyzer. Fibre length, coarseness (fibre wall thickness), and microfibril angle all contribute to the end use potential of pulps.

Paprican's eminent fibre physicist, the late Dr. Raj Seth, reported that 4 attributes distinguish all pulps:

Fig. 2. The effect of fibre length on wet web strength (Seth 1995).

- Fibre length

- Fibre coarseness

- Fibre strength

- Uniformity

On the basis of these intrinsic attributes, Canadian fibre superiority and its reputation as a premium reinforcing pulp has been built in the global marketplace.

Seth (1995) reported a series of elegant experiments to prove these points. In the first, he took a softwood kraft pulp and cut the fibres so that the average fibre length was varied between $1 \mathrm{~mm}$ and $3 \mathrm{~mm}$. These samples were tested using a standard procedure, in this case wet web tensile strength, as shown in Fig. 2. The results clearly show that all things remaining equal in terms of other attributes of the pulp, the fibre length must be as long as possible in order to achieve maximum pulp strength.

He then repeated the experiment, but this time the fibre coarseness was varied as shown in Fig. 3. This inverse relationship, reported under 2 different conditions, shows that

${ }^{3}$ http://www.fpac.ca/en/media_centre/press_releases/2007/200710-30_carbonNeutral.php
Fig. 3. The effect of fibre coarseness on wet web strength (Seth 1995). 
low coarseness (fine-fibred) pulps, when corrected for fibre length, provide the highest reinforcement strength.

Coarseness variation between selected species is shown in Table 1. In short, lower fibre coarseness means higher sheet tensile strength, greater bonding area, and more fibres per tonne of pulp, all of which are attributes that are highly prized by technically sophisticated papermakers. A comparison with key competitor species from temperate and tropical regions is

Table 1. Properties of selected pulps

\begin{tabular}{lccccc}
\hline & $\begin{array}{c}\text { Fibre } \\
\text { length } \\
(\mathbf{m m})\end{array}$ & $\begin{array}{c}\text { Coarseness } \\
(\mathbf{m g} / \mathbf{1 0 0 m})\end{array}$ & $\begin{array}{c}\text { Fibre } \\
\text { diameter } \\
(\boldsymbol{\mu m})\end{array}$ & $\begin{array}{c}\text { Wall } \\
\text { thickness } \\
(\boldsymbol{\mu m})\end{array}$ & $\begin{array}{c}\text { Fibres/ } \\
\text { gram } \\
\left(\times \mathbf{1 0}^{\mathbf{6}}\right)\end{array}$ \\
\hline Coastal Douglas-fir & 3.4 & 24 & 42 & 4.0 & 1.8 \\
Western hemlock & 3.0 & 20 & 38 & 2.7 & 2.8 \\
Spruce/pine & 3.0 & 18 & 30 & 2.2 & 3.6 \\
Western redcedar & 2.9 & 16 & 28 & 1.6 & 4.2 \\
Southern pine & 4.1 & 30 & 47 & 4.8 & 1.1 \\
Radiata pine & 2.9 & 22 & 37 & 4.0 & 2.2 \\
Scandinavian pine & 2.8 & 20 & 35 & 2.9 & 2.8 \\
Black spruce & 2.8 & 18 & 30 & 2.2 & 3.6 \\
\hline
\end{tabular}

also included. Such differences in these key fibre properties confer significant differences in end use potential.

Uniformity is perhaps the attribute most prized by papermakers. Papermaking is both art and science. Paper machines take a fibrous mixture at $0.5 \%$ by weight in water, form and then dry a sheet of paper, which in some cases is less than a millimetre thick, to more than $95 \%$ solid at speeds in excess of $60 \mathrm{~km} / \mathrm{hr}$. The engineering tolerances are in the order of microns. The demands on the long reinforcing fibres are extreme, and the quest to reduce the expensive long-fibre content while also preserving final sheet properties is neverending. The stresses under which the sheet is prepared (and subsequently printed or converted) dictate that any non-uniformity in the sheet will result in paper breaks and expensive downtime both at the paper machine and worse, at the printing press or customers converting plant.

In order to achieve low sheet weight per square metre under such demanding conditions, a very narrow distribution of fine and readily collapsible earlywood fibres within a defined fibre length and coarseness range is the key. For

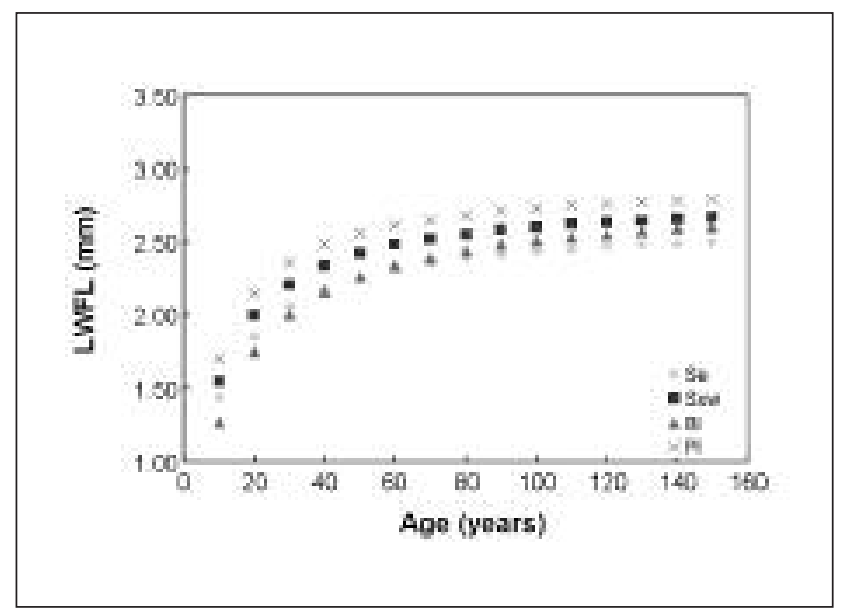

Fig. 4. Fibre length comparisons between BC spruce pine and fir samples over several biogeoclimatic zones. example, at CPLP, our natural endowment of spruce-pine-fir (SPF) is a uniform blend of these properties, since differences between these species are negligible, as shown previously in Table 1, and for fibre length in Fig. 4. In addition, the biogeoclimatic zones from which our fibre basket originates is generally quite uniform, and Paprican has undertaken extensive studies to characterize and quantify any potential differences.

Not surprisingly, variability within the SPF resource does occur and can be quantified in terms of growing site effects as shown in Fig. 5 for fibre length. Simple correlations against site index confirm that harsher growing sites produce shorter (and finer) fibres, which in turn increase the wood density. BC's biogeoclimatic subzone system can be used to further assess and predict the effect on fibre properties as shown in Fig. 6 , making this system, which is routinely used for stand harvesting and replanting only, additionally useful when one considers the opportunity for integrated supply chains and new enterprise models identified in Fig. 1.

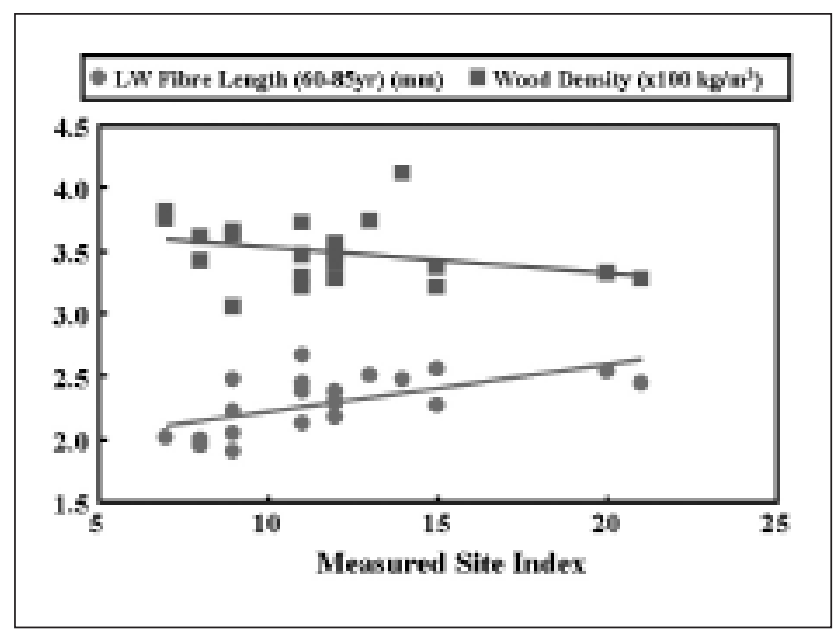

Fig. 5. Effect of site index vs. mature wood fibre length and wood basic density.

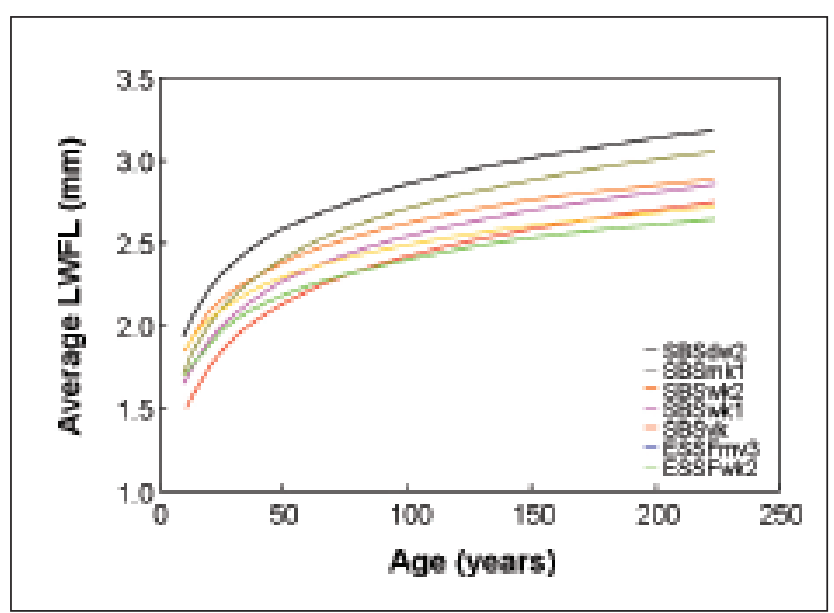

Fig. 6. Changes in fibre length as a function of biogeoclimatic subzone. 


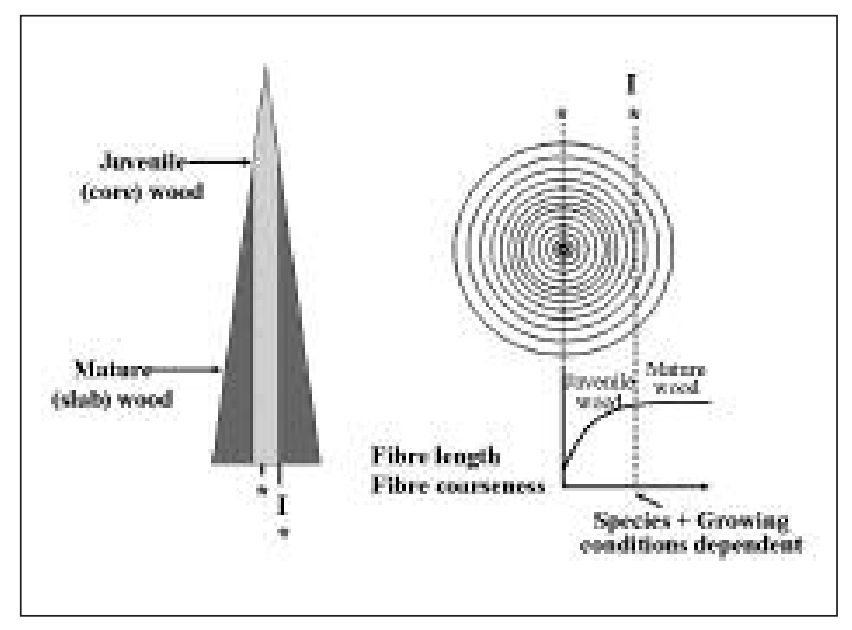

Fig. 7. Definition of juvenile vs. mature wood.

Finally, it is important to consider the effect of within-tree variability that is alluded to in Fig. 8. Fibre properties vary as a tree grows and are particularly pronounced for softwoods. The juvenile wood is characterized by continually increasing fibre length and coarseness with continuously decreasing microfibril angle. When the fibre properties stabilize, we consider this to be mature wood (the outer portion of the tree) as shown in Fig. 7. The juvenile wood portion of a tree is both species and growing-site dependent.

There are other definitions for characterizing juvenile and mature wood that are generally related to the end user (solid wood) or the jurisdiction (radiata pine). Although wood density is very simple to measure, it is a very poor predictor of juvenile to mature wood characteristics and is, as shown in Fig. 8, an even worse predictor of fibre properties.

For end users like CPLP, who consume sawmill residual chips produced from the mature or outer (slab) wood portion of a tree as it is processed through a sawmill, juvenile wood is generally a minor component of the fibre supply basket and hence causes no issues. However, these are exceptional times with the sawmill sector currently facing extremely unfavourable market conditions coupled with significant levels of dead lodgepole pine as a consequence of the mountain pine beetle epidemic. In response, CPLP is currently utilizing a portion of whole-log chips that will obviously contain shorter, finer-fibred juvenile wood. Hatton (1997) has reported that the proportion of juvenile wood in older stems is low, only $15 \%$ at 150 years. At 60 years of age, the proportion of juvenile wood is $50 \%$ and at 20 years is $100 \%$. Hence, until much higher levels of roundwood chips are consumed, there is no impact of juvenile wood on pulping operations or pulp quality. Perhaps more importantly, Hatton's (1997) data also confirms that juvenile wood is a greater issue for those softwoods grown on short rotations, particularly when growing-site effects are also taken into consideration.

Finally, differences in fibre quality can exist as a function of genetic effects. This effect is widely recognized to be less pronounced than the impact of growing site for softwood species. Opportunities to select genetically improved trees with enhanced wood quality exist, but unless the rotation age
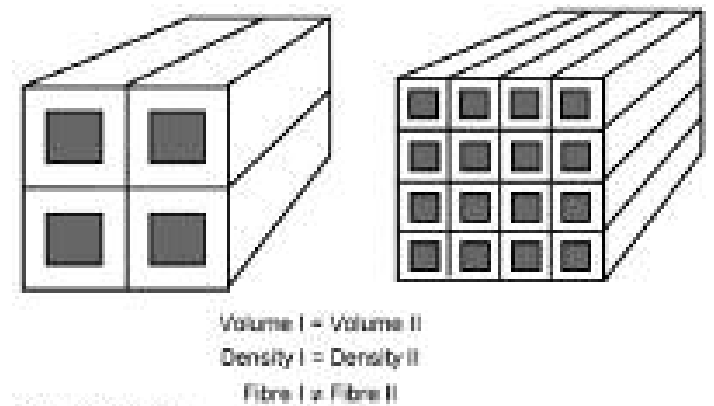

Sware: Entowtis.

fitre Iz Fitell

Fig. 8. Definition of fibre properties impact on wood density.

is very short, e.g., Brazilian eucalyptus, the ability to measure and assess relative value, such as genetic gain, may be limited. This is true even considering advances in wood properties analysis techniques for phenotyping and the development of DNA-based rapid assessment tools.

\section{Global Positioning of Canadian fibres}

The performance of Canadian NBSK pulps in the global marketplace is the ultimate determinant of the importance of fibre attributes to end-product quality and cost. The pulp samples considered here are all softwood market pulps, bleached with either ECF or TCF processes. Unlike previous experiments where the refining was usually conducted using the ultra-low intensity PFI mill, these samples were all refined on a pilot refiner at an intensity and consistency similar to that of an operating mill. Standard handsheet preparation procedures were followed and all testing was with TAPPI or PAPTAC conditions and methods. In total, 85 samples were tested, representing all pulp-producing regions globally. Some mills were tested more than once.

For these analyses, the key fibre properties that control the reinforcing potential of a pulp were evaluated (Palsanen 1979, Paavilainen 1993, Seth 1995). On the paper machine, wet and dry tensile strength, tearing strength (for some applications), density, porosity and fracture toughness, were also key variables considered in this study since they are all known to be critical to product performance and machine efficiency.

Using this information to rank pulps by intrinsic property, we can see a clear geographic component to the distribution. Since it has been shown that the fundamental properties are affected by climate, species and site, such a regional component to these rankings is to be expected (Fig. 9).

Turning to properties of the actual paper produced, we expect that the geographic influence on the intrinsic properties should be apparent in the paper, and that is exactly what we do see (Fig. 10).

There are many other important properties that exhibit a similar geographic ranking, with the Canadian fibres tending to cluster at one end of the distribution. While there may be some fibres that can match Canadian fibres in specific prop- 


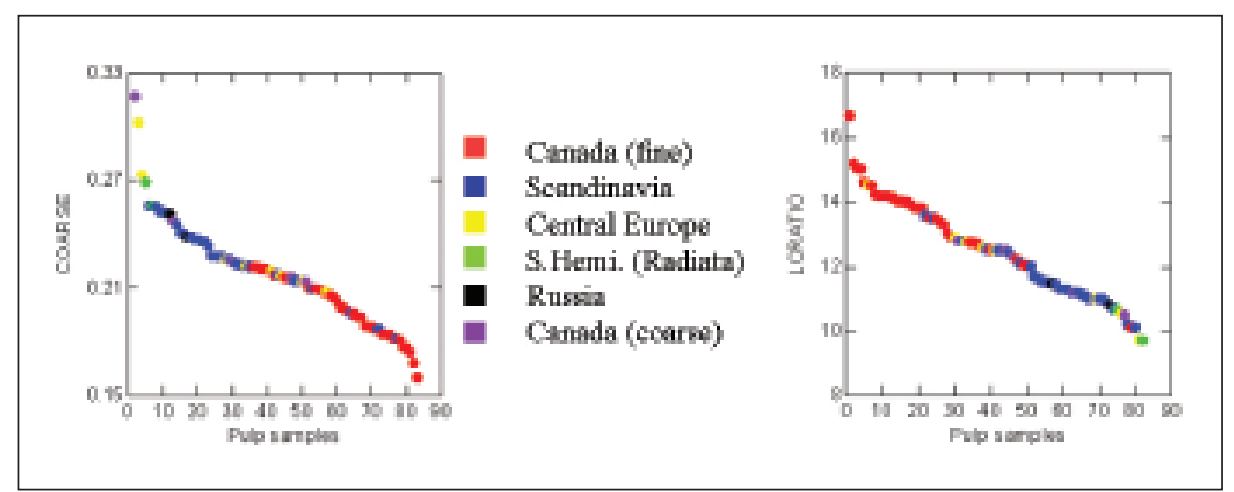

Fig. 9. Pulp rankings by coarseness and length/coarseness ratio.

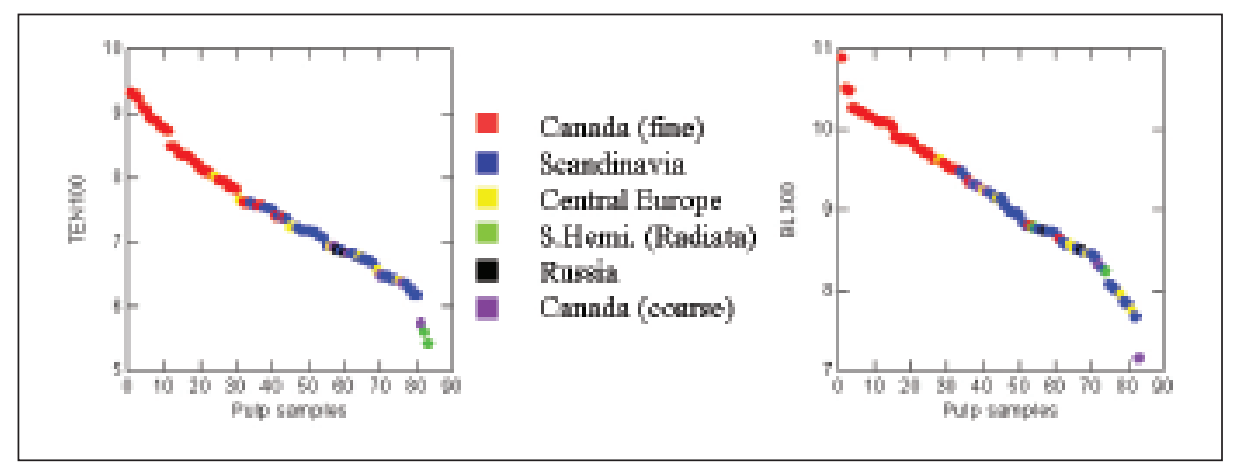

Fig. 10. Pulp ranking by paper properties_breaking length at $100 \mathrm{kWh} / \mathrm{t}$ and $300 \mathrm{ml}$ freeness. most heavily by a combination of key properties involved in the determination of pulp strength (tensile, tear, density, freeness). We refer to this factor as the Strength Factor. The second factor explained an additional $17 \%$ of the variance, and was loaded most heavily by refining and morphological components. We refer to this factor as the Morphology Factor.

Plotting the standardised factor scores (Fig. 11) reveals some very distinct groupings. Ellipses based on sample standard deviations ( $\mathrm{x}, \mathrm{y})$ and covariances (orientation) have been added using a probability level of 0.8 . The Canadian fibres range across a large part of the Morphology Factor range, which was expected given that the variety of fibres represented range from western redcedar to western hemlock and jack pine. However, the Canadian pulps dominate the high end of the Strength Factor range, and in general, there is a clear clustering of data by broad geographic region of origin.

To illustrate the practical use erties, there are none that can match them in all. To gain a better understanding of the effect of the combination of properties, we applied multivariate data reduction techniques. All independent data from our testing were included in the analyses; the only data excluded were those for which codependencies existed, i.e., length:coarseness ratios. Coastal Canadian fibres containing Douglas-fir were identified as Canada (coarse) in this process.

Non-hierarchical Cluster Analysis, a procedure appropriate for grouping items such as individual pulps rather than variables, was used to conduct preliminary analysis of the data. Using the K Means algorithm in Systat, it became clear that the data associates into 2 clusters as seen in Table 2. All of the Canadian low coarseness (fine) pulps and one Scandinavian pulp fell into one cluster, with all other pulps forming a second cluster. The Scandinavian pulp that fell in the first cluster was in fact one that enjoys the reputation of being one of the best reinforcing pulps from that region. Therefore the world's softwood market pulps can be divided into 2 clusters, one of which encompasses the pulps that have the reputation as being superior reinforcing pulps.

Factor Analysis was then applied to explore whether there were fundamental structures present in our data. We used the Systat PCA algorithms to extract the factors and found that 2 factors accounted for $65 \%$ of the variance in the data set, and that additional factors were not significant (Humphrey-Illgen Parallel Analysis test; MacQueen 1967). The first factor explained almost half of the variance (48\%), and was loaded of this pairing of Strength and Morphology Factors for the papermaker, let us consider 2 Light Weight Coated (LWC) papermakers, one using traditional technology and the other using a film press. In both cases, the papermaker requires a softwood kraft pulp-the stronger the better-to reinforce their own production of mechanical pulps. Most Canadian pulps seem to qualify, but in the case of the traditional technology, the papermaker needs a fibre that does not close up the sheet too much in order to prevent a printing defect known as "fluting." Therefore, the papermaker would select a pulp that was low on the morphology axis. In the case of the film press, the requirement is for the sheet structure to be quite sealed to minimize coating penetration and hence a pulp with a higher score on the Morphology scale would be indicated. This is, in fact, a standard practice for many producers of these paper grades.

Table 2. Result of the K Means Cluster Analysis

\begin{tabular}{|c|c|c|c|}
\hline \multicolumn{2}{|l|}{$\begin{array}{c}\text { Group } 1 \\
49 \text { members }\end{array}$} & \multicolumn{2}{|c|}{$\begin{array}{c}\text { Group } 2 \\
36 \text { members }\end{array}$} \\
\hline Central European & 7 & Canadian & 35 \\
\hline Scandinavian & 28 & Scandinavian & 1 \\
\hline Radiata & 4 & & \\
\hline Canada coarse fibres & 7 & & \\
\hline Russian & 3 & & \\
\hline
\end{tabular}


PRP Factor Scores

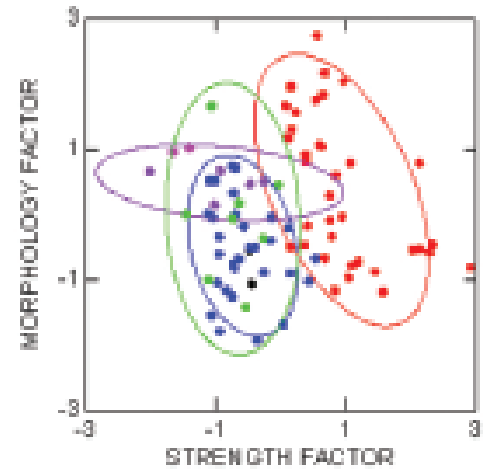

Fig. 11. Plot of standardized Factor Scores.

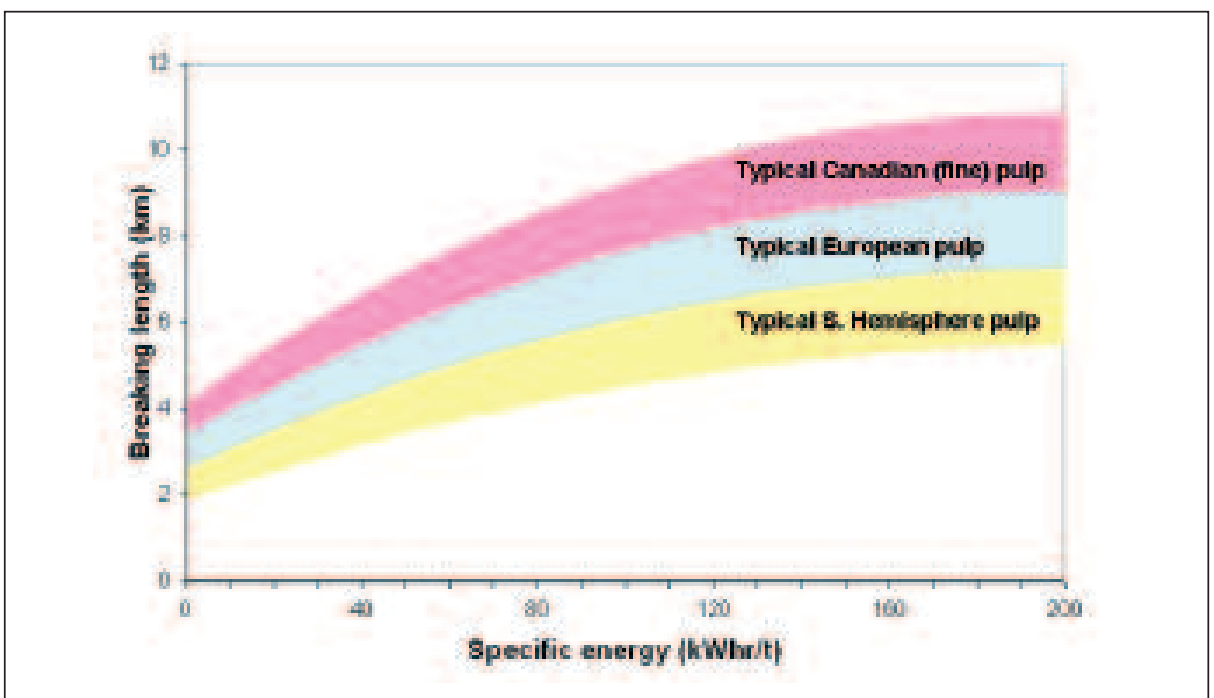

Fig. 12. Ranking of market softwood pulps by tensile strength.
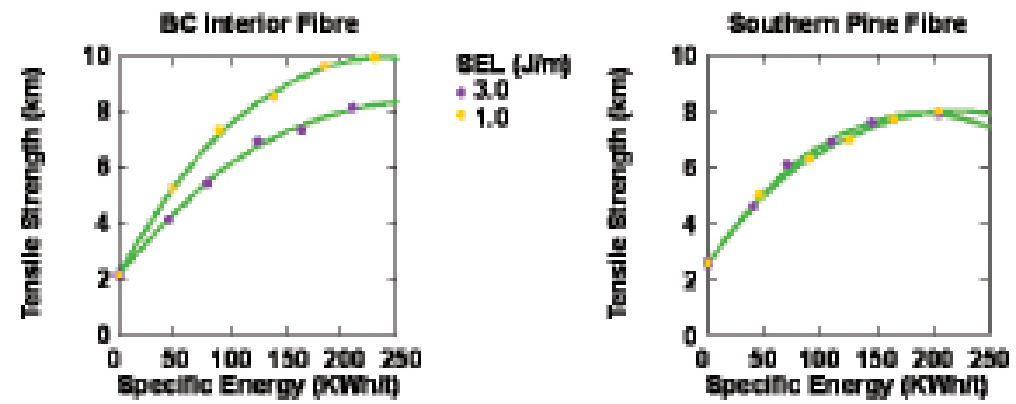

- Lower specific edge lood produces higher ternsie strengthes

- Finer fibres will always produce higher tensile strengths then coarser fibres
What the Customer Sees

Most sophisticated papermakers will conduct some sort of test on their purchased pulps to determine their reinforcing abilities, most commonly by measuring their response to mechanical refining over a range of energy inputs. When this evaluation is conducted on world market pulps, a wide range of different strength levels is consistently observed (Fig. 12). Canadian pulps produced from fine-fibred species are always at the top of the family of curves.

When refining softwood kraft pulps to achieve desired papermaking properties, it is known that optimal results can be obtained when lower refining intensities are used, but this only occurs when finer fibres are being treated (Fig. 13). While the full mechanism operating to cause this effect is still the subject of investigation, the effect itself is clear, and it favours Canadian fibres.

Levlin (1991) has proposed 2 indices to measure the reinforcement potential of a pulp. Using the index for LWC papers as an example, it is possible to rank pulps for their suitability, as shown in Fig. 14, which is taken from a publication by Jaakko Pöyry and Leena Paavilainen (1999). Once again, Canadian pulps are seen to provide superior performance.

Other examples exist that demonstrate the position held by the Canadian fibres. The marketplace sees clearly that Canadian softwood fibres possess a set of properties that are not available from other producing regionsso clearly, in fact, that competitors have launched strategies with titles like "Matching the Canadians." Much of the investment by our competitors during the last decade has focused on trying to close the gap between their intrinsic fibre properties and ours, including fibre selection and fibre fractionation.

Fig. 13. Effect of Coarseness on refining response (Seth 1996). 


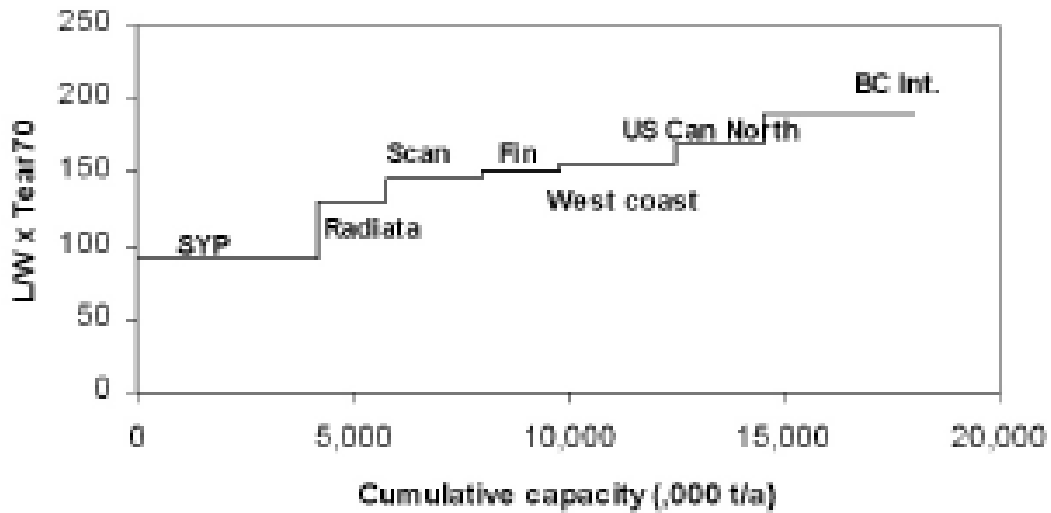

Souer Poyn, Prwilaition

Fig. 14. Reinforcement ranking for softwood kraft pulps.

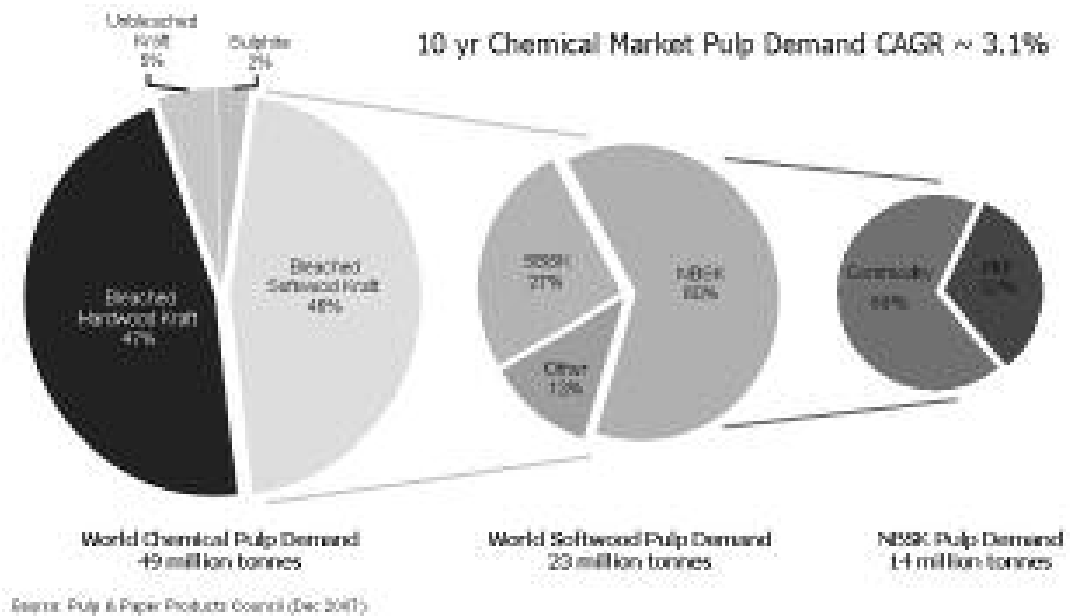

Fig. 15. Global market pulp demand

\section{Concluding Remarks - Maintaining and Strengthen- ing Our Advantage}

It is well established in global markets that Canadian softwood kraft pulp producers have a significant quality advantage over all other jurisdictions due to the key attributes of fibre length, fibre coarseness, pulp strength and uniformity. Significant diversity of attributes between tree species exists within some jurisdictions, but operationally, such variability is minimized and different grades of pulp are manufactured. Juvenile wood, growing environment and genetics can play a role in fibre quality variability, but for many producers, the provenances from which the wood is sourced tend to fall within similar growing conditions, hence variability is minimized. For softwoods, the key properties affecting the performance of a pulp are determined by "geography and climate" (Dillner n.d.). Canadian reinforcing pulps are highly prized worldwide both by very sophisticated papermakers manufacturing a range of specialty products, and also by producers of high-volume, high-performance publication papers.

The global market for softwood kraft pulps (Fig. 15) currently stands at 23 million tonnes, of which 14 million tonnes are northern bleached softwood krafts (NBSK). By the current authors' assessment, approximately $50 \%$ of this pulp is being used in applications that take significant advantage of its unique properties, and almost all of this pulp originates in Canada.

While some Canadian suppliers see these superior reinforcing properties reflected in various ways in the premiums they achieve, others do not. Some Canadian suppliers do not even seem to know they exist! Canadian fibres have the ability to deliver significant costreduction opportunities to papermakers and market advantage to the suppliers, provided that their properties are well understood and they are marketed wisely. The competition may actually better understand the advantages of our pulps than some of us do, (if they did not, their customers would certainly tell them). The challenge for Canada is to more fully understand our natural advantages and find ways to exploit them further. Investment in plants and research and development, coupled with developing an innovation culture, will help us to maintain the superiority and marketability of Canadian fibre. If we do not encourage investment in these areas, we should expect the gap Canadians enjoy over the global competitors to continue to erode, and our superior pulps to wither into commodity ones. 


\section{References}

Dillner, B. n.d. Fibre in focus II. Södra Pulp Academy.

Hatton, J.V. 1997. Pulping and papermaking properties of managed second growth softwoods. Tappi Journal 80(1): 178-184.

Kibblewhite, R.P. and J.M. Uprichard. 1996. Kraft pulp qualities of eleven radiata pine clones. Appita Journal 49: 243-250.

Levlin, J.E. 1991. The role of softwood kraft pulps in printing and writing papers. Paperi ja Puu 73(6): 512-516.

MacQueen, J.B. 1967. Some methods for classification and analysis of multivariate observations. Proceedings of $5^{\text {th }}$ Berkeley Symposium on Mathematical statistics and Probability, 1. pp.281-297. University of California Press, Berkeley, CA.

Paavilainen, L. 1993. Importance of cross-dimensional fiber properties and coarseness for the characterization of softwood sulphate pulp. Paperi ja Puu 75(5): 35-43.
Paavilainen, L. 1999. Jaakko Pöyry, Papercast conference, Brussels. Palsanen, J. 1979. Der Einfluß der Streichrohpapiereigenschaften auf die Abrißempfindlichkeit in der Streichmaschine bei LWCPapier. Wochenblatt für Papierfabrikation 107(11/12): 432-435.

Seth, R.S. 1995. The effect of fiber length and coarseness on the tensile strength of wet webs: a statistical geometry explanation. Tappi Journal 78(3): 99-102.

Seth, R.S. 1996. Optimizing reinforcement pulps by fracture toughness. Tappi Journal 79(1): 170-178.

Seth, R.S., 1999. Beating and Refining Response of Some Reinforcement Pulps. Tappi Journal 82(3): 147-155. 